\title{
Transcriptional Control of Mesenchymal Stem Cell Differentiation
}

\author{
Jess Frith Paul Genever \\ Department of Biology (Area 9), University of York, UK
}

\section{Key Words \\ MSCs · Cbfa- 1 - PPAR- $\gamma \cdot$ Sox 9 - Transcription factors}

\section{Summary}

In recent years, transcriptomics and proteomics have provided us with a great deal of information about the expression profiles of various cell types and how these change under different conditions. Stem cell research is one area where this has had a major impact by providing an insight into events at the molecular level that control stem cell growth and differentiation. This includes mesenchymal stem cell (MSC) biology where knowledge about the mechanisms governing differentiation is vital for the development of future therapeutic strategies. Although there is still much to learn, we are starting to build up a picture of the main events in these differentiation processes. This review will discuss control of MSC differentiation at the transcriptional level. Not all the factors which have been shown to play a role in lineage-specific mesenchymal differentiation can be covered here. Instead, we will focus specifically on the key factors that contribute to the regulation of osteogenesis, adipogenesis, and chondrogenesis.

\section{Osteogenesis}

The differentiation of mesenchymal stem cells (MSCs) into mature osteoblasts involves several phases, starting with cellu-

\section{Schlüsselwörter \\ MSCs · Cbfa-1 · PPAR- $\gamma \cdot$ Sox9 - Transkriptionsfaktoren}

\section{Zusammenfassung}

Transkriptionskontrolle der mesenchymalen

Stammzelldifferenzierung

In den vergangenen Jahren bescherte uns die Transkriptomik und Proteomik eine Menge an Informationen über die Expressionsprofile von verschiedenen Zelltypen und darüber, wie sich diese unter verschiedenen Bedingungen ändern. Stammzellforschung ist ein Bereich, in dem dies einen großen Einfluss hatte, weil dort Einblicke erzielt wurden, wie Stammzellwachstum und -differenzierung auf molekularer Ebene kontrolliert werden. Das schließt auch die Biologie der mesenchymalen Stammzellen (MSCs) mit ein, wo das Wissen über die Mechanismen, die die Differenzierung steuern, entscheidend ist für die Entwicklung zukünftiger therapeutischer Strategien. Obwohl immer noch vieles nicht bekannt ist, beginnt man die Hauptereignisse innerhalb der Differenzierungsprozess zu verstehen. Die Kontrolle der MSC-Differenzierung auf Transkriptionsebene bildet den Schwerpunkt der vorliegenden Übersicht, wenn auch nicht alle Faktoren, die bei der abstammungsspezifischen mesenchymalen Differenzierung eine Rolle spielen, hier dargestellt werden können. Stattdessen wollen wir uns besonders auf die Schlüsselfaktoren, die zur Regulation der Osteogenese, der Adipogenese und der Chondrogenese beitragen, beschränken.

lar proliferation before progressing on to extracellular matrix (ECM) maturation and finally matrix mineralisation. Throughout this process, the cells mature through a series of intermediates, from committed osteoprogenitors to pre-

\begin{tabular}{ll}
\hline KARGER & $\odot$ 2008 S. Karger GmbH, Freiburg \\
Fax +49761 45207 14 & Accessible online at: \\
$\begin{array}{l}\text { E-mail Information@Karger.de } \\
\text { www.karger.com }\end{array}$ & www.karger.com/tmh
\end{tabular}

Dr. Paul Genever

Department of Biology (Area 9)

University of York

York YO10 5YW, UK

Tel +44 1904 3286-49, Fax -59

E-mail pg5@york.ac.uk 
Fig. 1. Expression levels of transcription factors and osteoblastrelated genes during osteogenesis. The onset of differentiation is marked by a decrease in Twist and an increase in Cbfa-1 and Osterix expression. Committed pre-osteoblasts show increased expression of Msx and Dlx proteins which interact and, together with Cbfa-1 and osterix, coordinate the expression of osteoblastspecific genes. Alkaline phosphatase is expressed during the early stages of osteogenesis, and osteonectin, osteocalcin, and osteo-

pontin are expressed by more mature osteoblasts during the phases of matrix maturation and mineralisation.

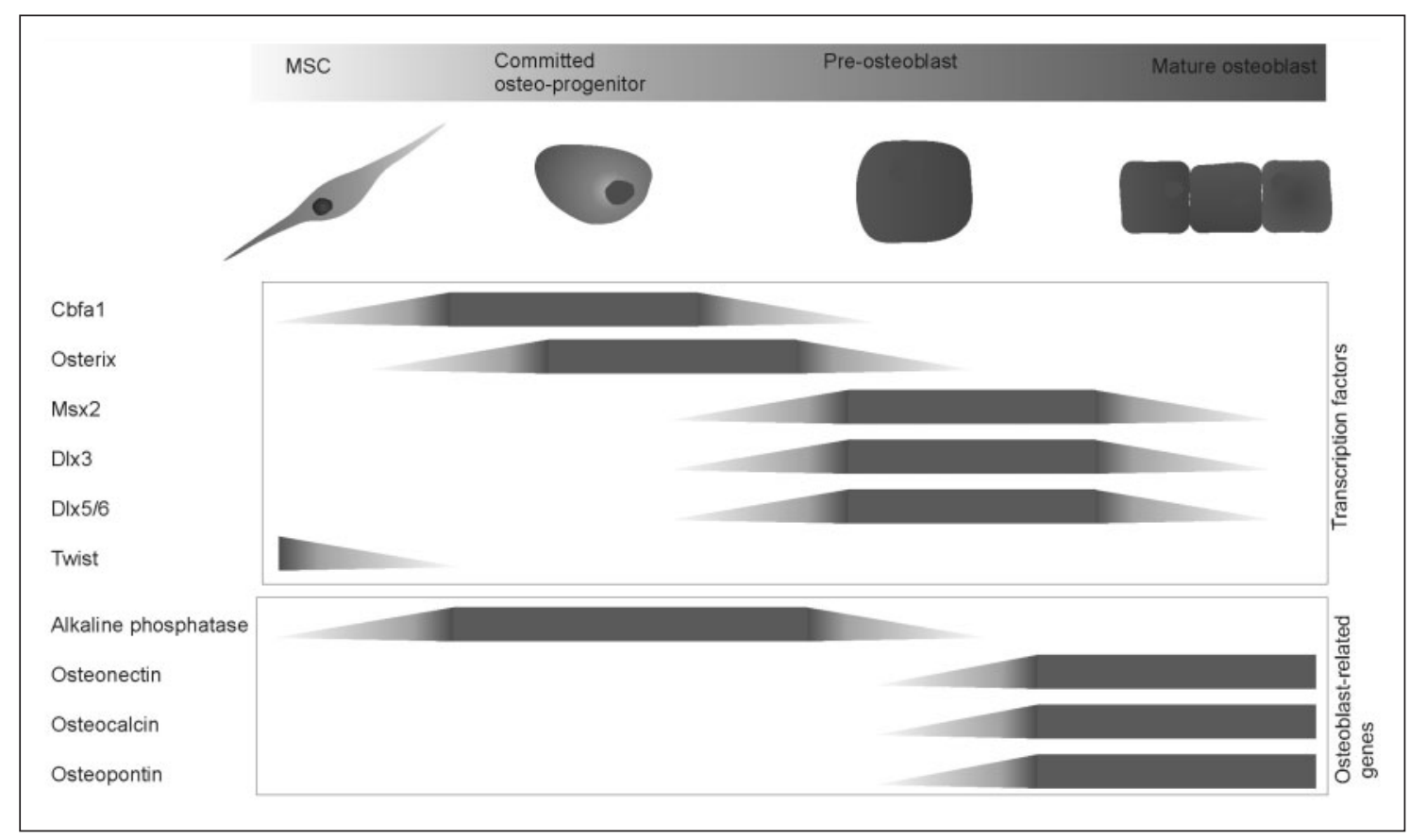

osteoblasts and terminally differentiated osteoblasts. Osteogenesis is regulated by many of the major developmental signalling pathways including bone morphogenetic protein (BMP), Wnt and Hedgehog signalling. These converge on, and exert their effects through, transcription factors that regulate gene expression profiles and consequently cell behaviour (fig. 1). BMP-2 is a potent inducer of osteogenesis and can be used to promote differentiation in vitro [1]. It is also common to use an osteogenic cocktail of dexamethasone, ascorbate, and beta-glycerophosphate. Although both of these methods are sufficient to induce osteogenic differentiation, it is likely that they act through different signalling mechanisms and induce different transcriptional activities.

\section{Cbfa-1}

Cbfa-1 (core binding factor $\alpha 1$, also known as Runx2/ Pebp $2 \alpha \mathrm{A} / \mathrm{AML} 3)$ is a runt-domain transcription factor expressed at sites of bone formation in the developing embryo [2] and more specifically in early osteoblast progenitors $[1,3]$. Cbfa- 1 was cloned as the factor that bound to an osteoblastspecific cis element in the osteocalcin promoter [4]. Overexpressing Cbfa-1 in MC3T3-E1 preosteoblastic cells demonstrated increased expression of the bone-associated markers type-I collagen, osteopontin, and bone sialoprotein [4], and binding sites for Cbfa- 1 have been identified in the promoters of type-I collagen, bone sialoprotein, osteopontin, and osteocalcin $[4,5]$, indicating a role for Cbfa- 1 as an osteoblast-specific transcription factor. Cbfa-1-null mice showed a complete absence of bone, with a purely cartilaginous skeleton. Together with an absence of mature osteoblasts, these data suggested that a lack of Cbfa-1 prevents osteogenic differentiation [6,7]. Later studies went on to show that Cbfa- 1 can induce osteogenesis in vitro and in vivo. MSCs overexpressing Cbfa- 1 differentiated into osteoblasts in the absence of osteogenic supplements, with increased expression of several osteoblastic markers and matrix mineralisation, and accelerated the healing of critical size defects in the skulls of mice [2].

There are conflicting reports on the potency of Cbfa-1, with some showing that ectopic expression of Cbfa- 1 is sufficient to promote osteogenesis [2], whilst others conclude that overexpression of Cbfa-1 actually reduces the amount of bone formation. Transgenic mice, with osteoblasts expressing Cbfa- 1 under the control of the type-I collagen promoter, had osteopenia, multiple fractures, and fewer mature osteoblasts than wild-type controls [8]. The discrepancy in these results may reflect the fact that Cbfa- 1 could have differential effects on early and late osteogenesis, promoting differentiation at early stages but having an inhibitory effect on terminal differentiation [8]. Cbfa-1 is a downstream target of BMP and transforming growth factor $\beta$ (TGF $\beta$ ) signalling, both of which are known to be potent inducers of osteogenesis [9-11]. Treatment with BMPs upregulates Cbfa- 1 expression in osteogenic precursors $[4,9]$. It is also known that Cbfa- 1 interacts with other transcription factors and that these interactions can alter the transcriptional profile, providing additional levels of control to the signalling mechanisms governing osteogenesis.

\section{Osterix}

Nakashima et al. [9] identified Osterix (Osx) as a zinc fingercontaining transcription factor specifically expressed in all de- 
veloping bones. Osx-null mice lacked bone formation and were born with a cartilaginous skeleton. This phenotype was similar to the Cbfa-1 knockout mice, although these also showed some cartilage defects whilst the effects of Osx deficiency were restricted solely to osteoblasts. Investigation of the cartilage elements of Osx-null mice revealed that they had been invaded by mesenchymal cells but these could not deposit bone matrix, suggesting that Osx was required for the differentiation of MSCs into osteoblasts. Importantly, these mesenchymal cells expressed Cbfa-1, indicating that Osx acts downstream of Cbfa-1 in osteogenesis. It has been suggested that Cbfa- 1 commits MSCs to osteochondral lineages, and that later expression of Osx restricts differentiation to osteogenesis [12].

Studies on the effects of Osx overexpression on osteogenesis have variable results. Some indicate that Osx alone is sufficient to induce osteogenesis $[9,13,14]$ whilst others indicate a positive-regulatory role that is also dependent on other factors [15]. These studies cover the expression of a variety of osteoblast-specific genes expressed at different stages of differentiation and more recently it has become accepted that Osx promotes the earlier stages of osteogenesis but is not sufficient to orchestrate events through to terminal differentiation [16]. It has also been demonstrated that Osx overexpression increases the proliferation of mesenchymal cells as well as providing commitment to the osteogenic lineage $[15,14]$.

\section{Msx/Dlx Proteins}

Msx and Dlx homeodomain transcription factors are homologues of the Drosophila Distal-less and muscle-specific homeobox genes, respectively. The Dlx and Msx proteins have diverse roles in regulating development and patterning whilst Dlx3 Dlx5, Dlx6, and Msx2 have been specifically implicated in osteogenic differentiation. The involvement of Dlx proteins in osteogenesis was suggested by their expression both at sites of bone formation during embryogenesis and in osteoblasts themselves [17-20]. It was later shown that the expression levels of the various Dlx proteins changes during the course of osteogenic differentiation. Dlx3 is expressed early in osteogenesis with Dlx5 and Dlx6 expressed at later stages. Dlx5 and Dlx6 levels then remain elevated through to matrix mineralisation [21-23]. Dlx5 and 6 are the most widely studied in connection with osteogenesis, and have some functional redundancy as well as individual roles. Dlx5-deficient mice have craniofacial abnormalities and a mild delay in ossification of the long bones whilst Dlx5/Dlx6 double mutants have more severe defects [24-26]. In addition to this, Dlx5 is upregulated during osteogenesis and has a positive effect on differentiation inducing osteogenic markers and promoting mineralisation of preosteoblasts in culture $[19,23,27,28]$. Dlx3 also promotes osteogenesis although its specific function is less clear as Dlx3 knockout mice die early in development before sufficient skeletal development [29]. Overexpression of Dlx3 in osteoprogenitors induces expression of osteogenic markers, and inhibition of Dlx3 by RNAi reduces their expression, indicating that a positive-regulatory role for Dlx 3 is similar to that described for Dlx5and Dlx6 [22].

It has recently been suggested that Dlx 5 can act in a Cbfa-1dependent and independent manner [30]. Dlx5 is necessary for BMP2-induced osteogenesis [31,32]. It is expressed simultaneously with BMP2 and BMP4 during development and is induced by BMP signalling in vitro [32-36]. BMP2, through Dlx5, increased both Osx and alkaline phosphatase levels in Cbfa-1-deficient cells, challenging the requirement for Cbfa1 in all aspects of osteogenic development $[6,37]$. In addition, Dlx5 induction was not affected by cyclohexamide inhibition of de novo protein synthesis while the response of Cbfa1 to BMPs was $[20,38]$. These findings suggest that BMP signalling activates Dlx5 which induces Cbfa1 to regulate osteogenesis. Cbfa-1 can also upregulate Dlx5 and may form part of a positive feedback loop [16]. It remains to be seen how relevant this signalling mechanism is in vivo. Liu et al. [37] transplanted diffusion chambers, containing BMP2- and Cbfa-1-deficient cells, into the peritoneal cavity of mice. As predicted from in vitro observations, these cells expressed osteoblastic markers but failed to form bone. Therefore, it appears that whilst a Cbfa-1-independent pathway exists for Dlx5 in vitro it is unlikely to play a prominent role in vivo.

Msx 2 is one of 3 members of the Msx gene family and is thought to promote osteoblast proliferation and inhibit maturation. It was identified under conditions where the expected positive-regulatory actions of Cbfa-1 were not observed, pointing to the existence of an osteogenic inhibitor [21]. Later studies confirmed that Msx2 overexpression inhibited osteogenesis whilst a reduction in endogenous Msx2 promoted matrix mineralisation $[39,40]$. In addition, Msx2 is found associated with the osteocalcin promoter only when the gene is inactive [22]. However, Msx2 mutant mice have skull defects, resulting from reduced osteoblast numbers, and Msx1/Msx2 double-knockout mice also show severe limb defects. These observations would suggest that Msx2 was involved in promoting osteogenesis in vivo but could also reflect the positive influence of Msx2 on osteoprogenitor proliferation [41-43].

Recent work has begun to identify the cooperative actions of the Dlx and Msx proteins in osteogenesis, showing that their effects are brought about by interactions with other key transcription factors, including Cbfa1 and Osx. Several possible mechanisms have been proposed, all of which may have some influence. Despite the in vivo evidence to support a positive role for Msx2 in osteogenesis, it is more widely accepted that Msx2 and Dlx5 act antagonistically, with Msx2 inhibiting and Dlx5 promoting osteogenesis. The phenotype observed in the Msx2 knockout mouse may also not strictly represent the specific influence of Msx2 alone, but the overall effect when multiple signalling interactions are interrupted. One proposed mechanism suggests that Msx2 binds to elements in osteoblast-specific genes, and Cbfa-1, competing with and blocking Dlx5 binding [30]. Bound Msx2 would then repress gene 
Fig. 2. Expression levels of transcription factors and adipocyterelated genes during adipogenesis. $\mathrm{C} / \mathrm{EBP} \beta$ and $\mathrm{C} / \mathrm{EBP} \delta$ initiate adipogenenic differentiation and are expressed during commitment and mitotic clonal expansion (MCE) of pre-adipocytes. Expression levels of the inhibitor CHOP10 decrease at the end of MCE, and allow expression of $\mathrm{C} / \mathrm{EBP} \alpha$. $\mathrm{C} / \mathrm{EBP} \alpha$ and PPAR $\gamma$ as well as SREBP1 are expressed during adipocyte maturation, activating the expression of many adipocyte-specific genes including LPL, aP2, FAS, and

adiponectin.

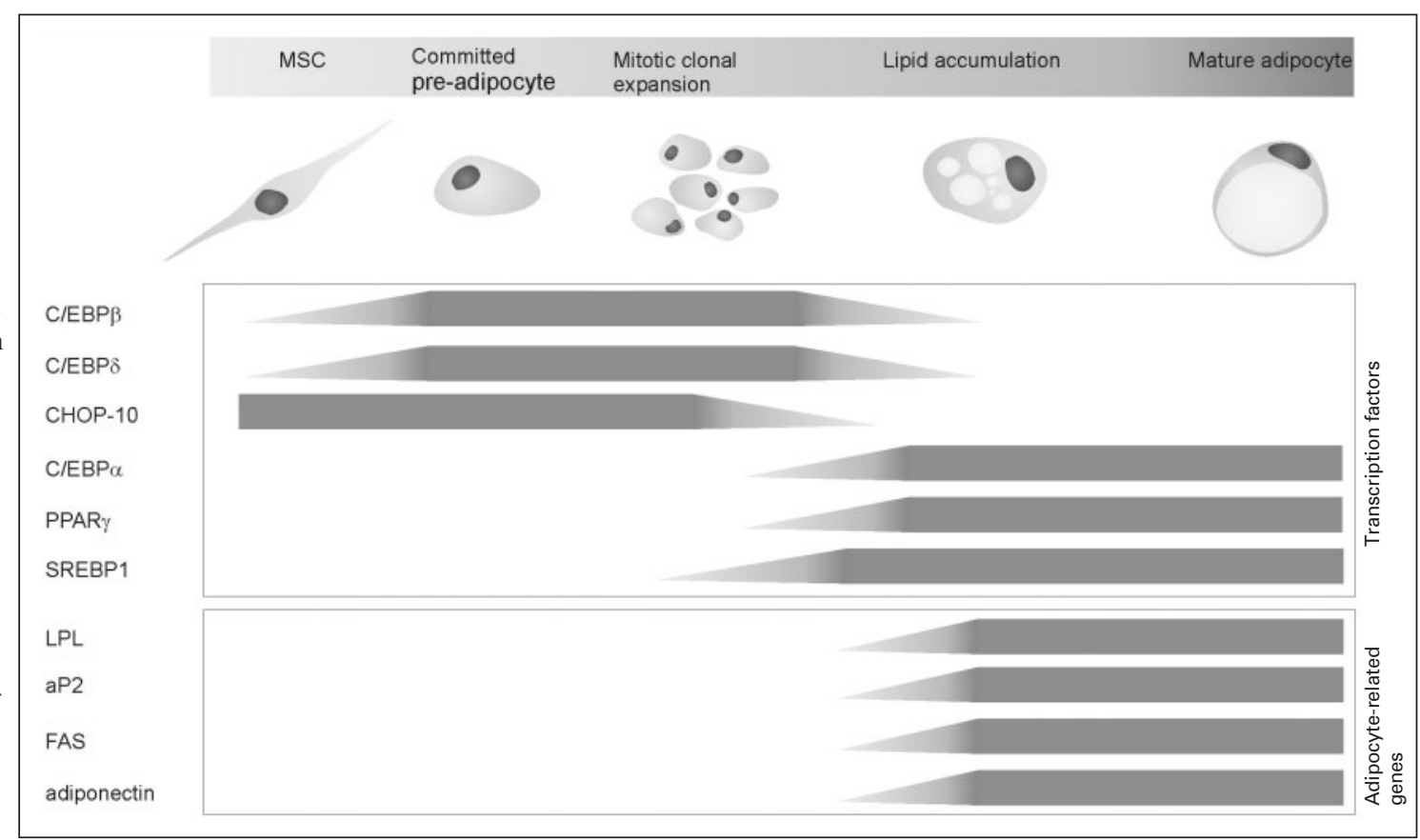

transcription and promote proliferation. In the later stages of osteogenesis, increased levels of Dlx5 would displace Msx2 and activate transcription through Cbfa- 1 promoter interactions [44]. The detailed repertoire of signalling interactions is likely to be more complex than this as the function of other factors is identified. Dlx 3 can also bind Cbfa- 1 but in this case the association was inhibitory and Dlx 3 binding directly to the osteocalcin promoter activated transcription [22].

\section{Twist}

Twist-1 and Twist-2 are basic helix-loop-helix (bHLH) transcription factors which have an inhibitory effect on osteogenesis [45, 46]. Homozygous Twist-1 knockout mice die before birth from a failure of the neural tube to close, but heterozygotes have craniosynostosis, increased bone formation in the skull caused by premature osteoblast differentiation [47, 48]. The inhibitory effect of Twist on osteogenesis therefore seems to be important in ensuring the correct timing of osteogenic differentiation and create correctly patterned skeletal structures. In vitro experiments support this hypothesis, showing that overexpression of Twist-1 suppresses BMP-induced differentiation [49]. Twist-mediated repression of osteogenesis acts through 2 pathways involving either Cbfa- 1 or histone deaceltylases. Repression through Cbfa- 1 is mediated via direct binding of Twist to Cbfa-1 through interactions between the Twist-box domain of Twist and the DNA-binding domain of Cbfa- 1 . This interferes with the binding and activation of osteogenic promoters by Cbfa- $1[50,51]$. Both Cbfa- 1 and Twist- 1 are expressed by preosteoblasts. Twist- 1 levels then decrease during the onset of differentiation. This helps to explain the observation that Cbfa- 1 expression occurs 4 days before osteoblasts become apparent in the developing embryo [51]. More recently, it was shown that Twist-1 suppresses osteogenic differentiation following BMP treatment. Co-immunoprecipitations revealed complexes containing Twist-1, Smad4, and histone deacetylase 1 (HDAC1) in MC3T3-E1 cells. Addition of an HDAC1 inhibitor increased BMP-signalling and osteogenesis, indicating that Twist may also repress osteogenesis by recruiting HDAC1 to Smad complexes thereby inhibiting transcription of osteogenic target genes [49]. Whilst we have discussed the major transcriptional regulators here, there are also a whole host of other factors that are involved in the regulation of osteogenesis acting independently or as co-regulators. These include activating transcription factor 4 ATF4, and p68 Ddx5 which are positive regulatory factors, and NKX3.2 and Pitx2 which negatively regulate transcription.

\section{Adipogenesis}

In a manner similar to osteogenesis, adipogenic differentiation of MSCs is initiated with the commitment to pre-adipocytes which express adipocyte-specific genes and mature into terminally differentiated, functional adipocytes. MC3T3-L1 cells are a pre-adipocyte cell line that can faithfully recapitulate the progression of adipogenesis, when treated with pro-adipogenic factors in vitro, and have been widely used, alongside primary MSCs, in studies to elucidate events controlling the adipogenic differentiation programme. In vitro, a cocktail of dexamethasone, isobutylmethylxanthine (IBMX), indomethacin, and insulin is used to promote differentiation. The addition of adipogenic supplements causes MC3T3-L1 cells to move from a 
growth-arrested state through rounds of proliferation (mitotic clonal expansion, MCE) to develop into mature adipocytes. The induction of adipogenesis is finely regulated by a balance between pro-adipogenic and anti-adipogenic signalling mechanisms. The pro-adipogenic factors include fibroblast growth factors (FGFs), insulin and insulin-like growth factor (IGF-1), prostaglandins, and glucocorticoids whilst Wnt3a, Wnt7a, TGF $\beta$, and Sonic hedgehog (Shh) have been shown to inhibit adipogenesis [52]. These upstream signalling pathways coordinate the actions of a number of signalling factors, most notably peroxisome proliferator activated receptor- $\gamma(\operatorname{PPAR} \gamma)$ and the CAAT/enhancer binding protein $(\mathrm{C} / \mathrm{EBP})$ family. The regulatory actions of these transcription factors then directs expression of fatty acid bind protein ( $\mathrm{aP} 2$, otherwise known as FABP4), fatty acid synthase (FAS), lipoprotein lipase (LPL), and glucose transporter 4 (GLUT4) and other adipocyte-specific genes, all of which produce the changes in ECM production, metabolism, and lipid accumulation associated with adipocyte maturation (fig. 2).

\section{PPAR}

Peroxisome proliferator activated receptor- $\gamma(\operatorname{PPAR} \gamma)$ is a nuclear hormone receptor that is widely acknowledged to be the master regulator of adipogenesis. Two different isoforms of PPAR $\gamma$ are produced by alternative splicing of the PPAR $\gamma$ gene. PPAR $\gamma 1$ is ubiquitously expressed whilst PPAR $\gamma 2$, with an additional 28 amino acids at the $\mathrm{N}$-terminus, has a more restricted expression pattern and is found mainly in adipose tissue $[53,54]$. PPAR $\gamma 2$ seems to be a more potent inducer of adipogenic differentiation [55]. PPAR $\alpha$ and PPAR $\beta$ are related proteins that have reduced adipogenic activity compared to $\operatorname{PPAR} \gamma[56]$.

PPAR $\gamma$ is both necessary and sufficient to induce adipogenic differentiation. Importantly, many other factors regulating adipogenesis mediate their effects through PPAR $\gamma$. Overexpression of PPAR $\gamma 2$ in cultured fibroblasts promoted adipogenic differentiation [57] and caused the transdifferentiation of myoblasts into adipocytes [58], but PPAR $\gamma$-deficient cells could not form adipocytes, even with the addition of other regulators of adipogenesis [59]. This key role of PPAR $\gamma$ has been confirmed in vivo with PPAR $\gamma$ knockout mice having decreased amounts of adipose tissue compared to wild-type littermates [60]. The mechanism of PPAR $\gamma$-induced transcription is initiated by the binding of ligand to the PPAR $\gamma$ receptor. In vivo, PPAR $\gamma$ ligands include fatty acids and eicosanoids. Thiazolidinediones (TZDs) are synthetic PPAR $\gamma$ ligands which increase sensitivity to insulin and are used as a treatment for diabetes [61, 62]. Ligand-binding induces a conformational change and allows the PPAR $\gamma$ receptor to complex with retinoid $\times$ receptor $\alpha(\mathrm{RXR} \alpha)$ forming a heterodimer. This, in turn, binds to peroxisome proliferator response elements (PPREs) and activates transcription of adipogenic target genes [63]. PPREs contain 2 repeats of AGGTCA separated by a single base pair [64].
Additional levels of PPAR $\gamma$ control include phosphorylation events and the activities of co-activator and repressor complexes. There are several potential phosphorylation sites in $\operatorname{PPAR} \gamma$, and when one or more of these sites are phosphorylated, transcriptional activity is decreased [65]. Co-factors interact with the PPAR $\gamma$-RXR $\alpha$ heterodimer to influence transcriptional activity and there may be as many as 200 proteins that are capable of doing this. In the absence of ligand, co-repressors bind to PPAR $\gamma$-RXR. Many of these either have intrinsic histone deacetylase activity, or recruit histone deacetylases, which keeps the chromatin tightly bound and represses transcription. The conformational change induced by ligand binding results in disassociation of repressors from the PPAR $\gamma$-RXR $\alpha$ complex and allows association of co-activators [66]. Co-factors of PPAR $\gamma$ include members of the steroid receptor co-activator (SRC) family. These, again, act through modification of the chromatin, but also allow recruitment of additional co-factors such as p300/CBP which are general transcriptional activators and interact with the basal transcriptional machinery [67-71].

\section{$C / E B P \alpha, \beta$ and $\delta$}

The CAAT/enhancer binding proteins (C/EBPs) are transcription factors with a C-terminal basic DNA-binding domain and a leucine zipper domain that facilitates homo- or heterodimerisation with other $\mathrm{C} / \mathrm{EBP}$ family members. Of the 3 family members, $\mathrm{C} / \mathrm{EBP} \alpha$ plays the most prominent role in coordinating adipogenesis by interacting with PPAR $\gamma$ and upregulating adipogenic gene transcription. $\mathrm{C} / \mathrm{EBP}$ binding motifs are found in the promoters of genes such as PPAR $\gamma$ and $\mathrm{aP} 2$, and expression of $\mathrm{C} / \mathrm{EBP} \alpha$ increases immediately prior to the expression of these markers $[54,72] . \mathrm{C} / \mathrm{EBP} \alpha-n u l l$ mice die shortly after birth due to the lost energy metabolism function of $\mathrm{C} / \mathrm{EBP} \alpha$. However, mice in which $\mathrm{C} / \mathrm{EBP} \alpha$ expression is restricted to the liver survive and show reduced adipose tissue formation caused by reduced numbers of adipocytes from arrested differentiation [73]. Loftus and Lane [56] confirmed this finding in vitro by antisense-mediated knockdown of endogenous $\mathrm{C} / \mathrm{EBP} \alpha$ in $3 \mathrm{~T} 3-\mathrm{L} 1$ pre-adipocytes. This reduced the expression of aP2 and GLUT4, and prevented lipid accumulation. In contrast, 3T3-L1 cells overexpressing $\mathrm{C} / \mathrm{EBP} \alpha$ were directed towards the adipogenic lineage, demonstrating that $\mathrm{C} / \mathrm{EBP} \alpha$ is sufficient to promote differentiation.

$\mathrm{C} / \mathrm{EBP} \beta$ and $\mathrm{C} / \mathrm{EBP} \delta$ are involved earlier on in adipogenesis than $\mathrm{C} / \mathrm{EBP} \alpha$ and seem to be initiators of differentiation rather than contributing to the maturation process, which appears to be the primary function of $\mathrm{C} / \mathrm{EBP} \alpha$. Both $\mathrm{C} / \mathrm{EBP} \beta$ and $\mathrm{C} / \mathrm{EBP} \delta$ are induced by adipogenic hormones, such as insulin and glucocorticoids. The major role of these factors is to promote the expression of $\mathrm{C} / \mathrm{EBP} \alpha$ and PPAR $\gamma$ which then drive forward terminal differentiation [56]. Mouse embryonic fibroblasts (MEFs) deficient in C/EBP $\beta$ do not progress through even the earliest stages of adipogenic differentiation, an effect that could be rescued by expression of functional, 
but not a dominant-negative C/EBP $\beta$ [74]. Further work showed that $\mathrm{C} / \mathrm{EBP} \beta$ activity impacts upon the MCE, which helps to explain why it is expressed immediately upon adipogenic induction, but does not bind to nor activate the promoters of $\mathrm{C} / \mathrm{EBP} \alpha$ and PPAR $\gamma$ until several hours later [72]. The delay in the transcriptional action of $\mathrm{C} / \mathrm{EBP} \beta$ is caused by a requirement for $\mathrm{C} / \mathrm{EBP} \beta$ to be phosphorylated in order to release it from the inhibitory activity of various cofactors, including C/EBP homologous proteins (CHOPs) [74, 75]. However, $\mathrm{C} / \mathrm{EBP} \beta$ also plays a direct role in $\mathrm{MCE}$, and $\mathrm{C} / \mathrm{EBP} \beta$ deficient cells are unable to undergo this round of expansion $[60,72]$. Exit from $\mathrm{MCE}$ is controlled by $\mathrm{C} / \mathrm{EBP} \alpha$ and $\mathrm{C} / \mathrm{EBP} \beta . \mathrm{C} / \mathrm{EBP} \alpha$ inhibits mitosis and is downregulated in the early stages of adipogenesis. When $\mathrm{C} / \mathrm{EBP} \alpha$ is induced by $\mathrm{C} / \mathrm{EBP} \beta$, it exerts its anti-mitotic effect thereby ending MCE and driving the cells onto the next stage of differentiation [75]. After their activation, PPAR $\gamma$ and $\mathrm{C} / \mathrm{EBP} \alpha$ act in a coordinated manner to propagate adipogenesis. Although PPAR $\gamma$ can stimulate adipogenic differentiation in the absence of $\mathrm{C} / \mathrm{EBP} \alpha$ [59], C/EBP $\alpha$ cannot in the absence of PPAR $\gamma$. However, the adipogenic effect of PPAR $\gamma$ on fibroblasts lacking $\mathrm{C} / \mathrm{EBP} \alpha$ is greatly reduced [76]. These $\mathrm{C} / \mathrm{EBP} \alpha$-deficient cells express reduced levels of PPAR $\gamma$, and cells deficient in PPAR $\gamma$ have reduced $\mathrm{C} / \mathrm{EBP} \alpha$ levels. This shows the co-stimulatory effect of both factors together, with PPAR $\gamma$ increasing C/EBP $\alpha$ expression and $\mathrm{C} / \mathrm{EBP} \alpha$ increasing PPAR $\gamma$ expression. This positive feedback loop maintains the high expression levels of both factors through to terminal differentiation, and it has been suggested that they are required for maintenance of the adipogenic phenotype as well as the initial differentiation process $[59,77,78]$. The expression of both PPAR $\gamma$ and C/EBP $\alpha$ together is sufficient to promote transdifferentiation of myoblasts into adipocytes [58].

\section{SREBP1/Add1}

Sterol regulatory binding element binding protein-1 (SREBP 1), also known as adipocyte differentiation and determination factor-1 (Add1), is another pro-adipogenic transcription factor. It is synthesised as a precursor, tethered to the endoplasmic reticulum and cleaved, producing an $\mathrm{N}$-terminal fragment that translocates to the nucleus to activate target gene transcription by binding both E-boxes and Sterol regulatory elements (SREs) [53, 79, 80]. Ectopic expression of SREBP1 in non-adipogenic NIH3T3 cells caused upregulated FAS and LPL expression, but did not result in overt adipocytic differentiation. Dominant-negative SREBP1 diminished the level of differentiation in 3T3-L1 adipocyte cultures [81]. SREBP1 augments PPAR $\gamma$-induced adipogenesis by directly stimulating PPAR $\gamma$ expression [82] and enhancing levels of PPAR $\gamma$ ligands [83].

\section{Negative Regulators of Adipogenesis}

In addition to the positive regulation of adipogenesis by $\operatorname{PPAR} \gamma, \mathrm{C} / \mathrm{EBP} \alpha, \beta, \delta$, and SREBP1, there are other factors that negatively regulate the transcription of adipocyte genes. These include the GATA-binding transcription factors (GATAs), CHOP, and inhibitor of DNA binding (Id) proteins. GATA factors were first connected to adipogenesis through their influence on fat body formation in Drosophila [84]. Tong et al. [85] showed that this adipogenic role was conserved in mammals with GATA factors acting as inhibitors of adipogenesis. Ectopic expression of GATA2 and GATA 3 held cells as pre-adipocytes whilst embryonic stem cells deficient in GATA2 and GATA3 showed an increased propensity to form adipocytes. In this initial work, it was demonstrated that GATA factors could bind directly to PPAR $\gamma$, inhibiting its transcriptional activity. Later it was shown that GATA2 and GATA3 formed complexes with both $\mathrm{C} / \mathrm{EBP} \alpha$ and $\mathrm{C} / \mathrm{EBP} \beta$ and that this interaction was necessary for GATA-mediated repression [86].

The pro-adipogenic factor SREBP1 is negatively regulated by Id proteins. The family consists of 3 members of which Id 2 and Id3 have been shown to interact with SREBP1 and control adipocytic gene expression. The expression of Ids declines during adipogenesis [87] allowing SREBP1 to exert its positive effect. Under non-adipogenic conditions, Id proteins physically interact with SREBP1 and prevent it from binding to DNA-regulatory sequences [88].

CHOPs negatively regulate adipogenesis through interactions with $\mathrm{C} / \mathrm{EBPs}$. In early adipogenesis, $\mathrm{CHOP}-10$ binds to and sequesters $\mathrm{C} / \mathrm{EBP} \beta$ preventing it from binding to DNA regulatory sequences to activate transcription. This is a key regulatory stage because inhibition of $\mathrm{C} / \mathrm{EBP} \beta$ prevents it from activating $\mathrm{C} / \mathrm{EBP} \alpha$ which inhibits the necessary clonal expansion of preadipocytes. During S-phase, CHOP-10 is downregulated, releasing $\mathrm{C} / \mathrm{EBP} \beta$ which in turn activates $\mathrm{C} / \mathrm{EBP} \alpha$ and ends $\mathrm{MCE}$. The continued effects of $\mathrm{C} / \mathrm{EBP} \alpha$ and PPAR $\gamma$ then allow adipogenesis to progress $[75,89]$. CHOP function is also influenced by physiological conditions. For example, CHOP expression is elevated under conditions of stress, including low glucose availability [90]. In this case, it may function to prevent the formation of adipocytes under conditions where the body does not have the resources to accumulate fat. It is interesting to note that all of the anti-adipogenic regulators seem to function through either PPAR $\gamma, \mathrm{C} / \mathrm{EBP} \alpha$, or both. This only serves to highlight their importance in the regulation of adipogenesis.

\section{Integration of the Actions of Pro- and Anti-Adipogenic Factors to Coordinate Adipogenesis}

The separate roles of each of the major adipogenic transcriptional regulators have been discussed above, but the actions of each of these intersect in a tightly regulated mechanism to drive adipogenesis (fig. 3). To summarise, pro-adipogenic hormones including insulin and glucocorticoid induce expression of $\mathrm{C} / \mathrm{EBP} \beta$ and $\mathrm{C} / \mathrm{EBP} \delta$ in pre-adipocytes. There is a lag in the transcriptional activities of $\mathrm{C} / \mathrm{EBP} \beta$ during which time it 
Fig. 3. Network of transcriptional regulation during adipogenesis. Adipogenic hormones induce the expression of $\mathrm{C} / \mathrm{EBP} \beta$ and $\mathrm{C} / \mathrm{EBP} \delta$ which activate $\mathrm{C} / \mathrm{EBP} \alpha$ and PPAR $\gamma$. Expression levels of $\mathrm{C} / \mathrm{EBP} \alpha$ and PPAR $\gamma$ are maintained throughout differentiation in a positive-feedback loop. These promote the expression of genes involved in adipocyte maturation and function, including lipoprotein lipase (LPL) and fatty acid synthase (FAS).

Negative regulators, such as CHOP-10, and Id 2 and Id 3 provide an additional level of control to regulate the process.

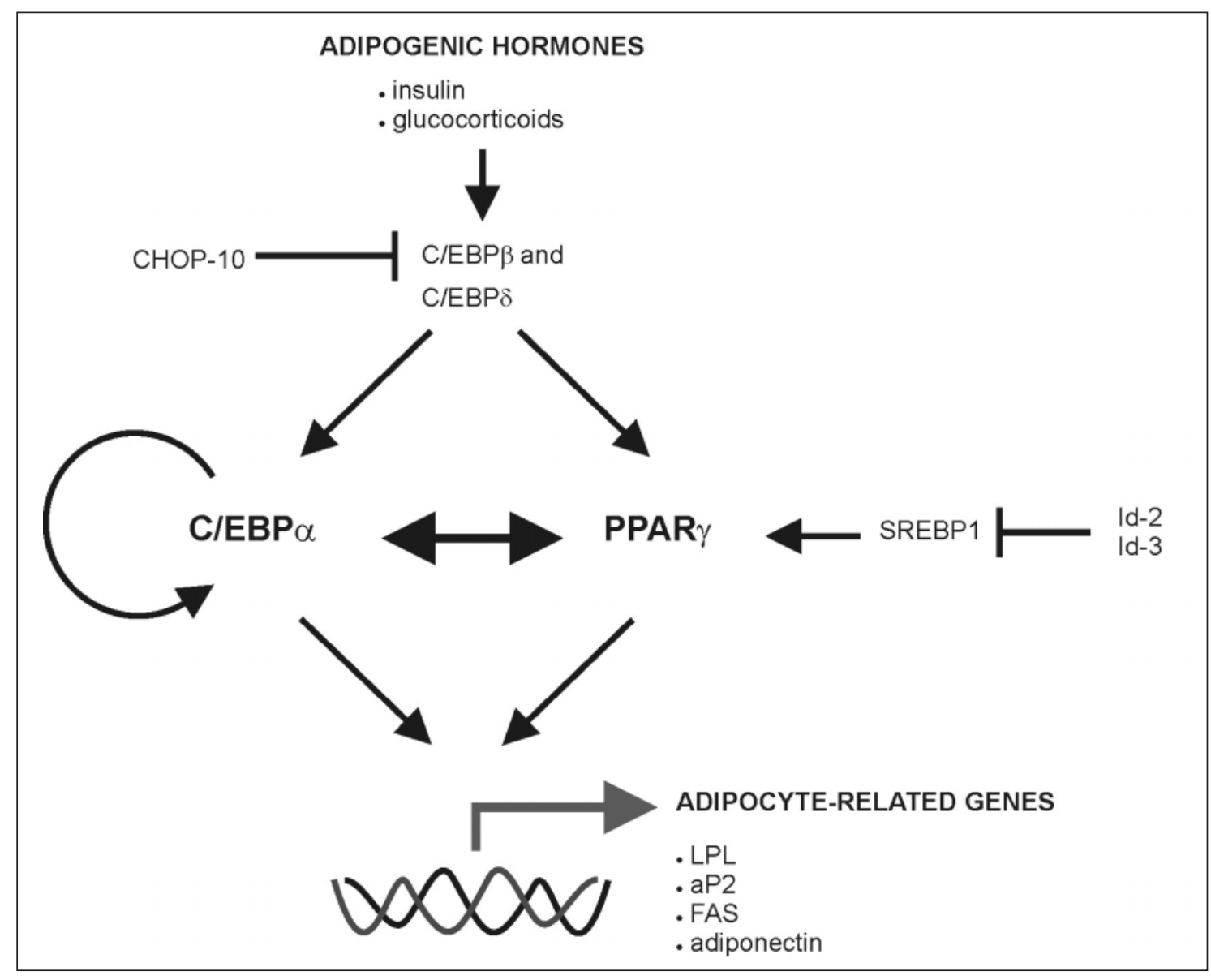

fulfils a role in promotion of the essential proliferative MCE. Phosphorylation of $\mathrm{C} / \mathrm{EBP} \beta$ releases it from interactions with inhibitory CHOPs upon which it activates expression of $\mathrm{C} / \mathrm{EBP} \alpha$ and PPAR $\gamma . \mathrm{C} / \mathrm{EBP} \alpha$ has anti-mitotic activity which terminates MCE and moves cells into overt differentiation. $\mathrm{C} / \mathrm{EBP} \alpha$ promotes expression of both itself and PPAR $\gamma$, whilst PPAR $\gamma$ also increases transcription of $\mathrm{C} / \mathrm{EBP} \alpha$ resulting in a positive feedback loop which maintains the expression of both of these factors through to terminal differentiation. $\mathrm{C} / \mathrm{EBP} \alpha$ and PPAR $\gamma$ are the transcription factors that then initiate expression of the adipocyte-specific genes that change the phenotype of the cells. This includes expression of aP2, GLUT4, FAS, LPL, and other genes which give rise to fatty acid synthesis and lipid accumulation. Other factors are also involved in this mechanisms including SREBP1 which promotes adipogenesis through the actions of PPAR $\gamma$ and GATA factors which are anti-adipogenic.

\section{Chondrogenesis}

The first stage of chondrogenic differentiation involves the condensation of mesenchymal cells, which is mimicked by the formation of micromass pellets when promoting chondrogenic differentiation in vitro. Concomitant with condensation are in- creased cell-cell and cell-ECM interactions, mediated by the upregulation of N-cadherin (N-cad), neural cell adhesion molecule (NCAM), and fibronectin (Fn) [91, 92]. During this phase, the cells become committed to the chondrogenic lineage and are described as pre-chondrocytes. After condensation, the cells progress into a highly proliferative phase, during which they are termed chondroblasts. These cells change their expression of ECM components from a matrix rich in type-I collagen typical of MSCs, to a more cartilaginous matrix containing type-II, type-IX, and type-XI collagen, aggrecan, and cartilage oligomeric matrix protein-1 (COMP-1). The proliferating chondroblasts have a flattened morphology and form highly ordered columns of cells before becoming progressively larger as they develop into pre-hypertrophic and then hypertrophic chondrocytes. Chondrocyte hypertrophy is marked by the expression of type-X collagen which is not expressed at any other stage of chondrogenesis. During endochondral ossification, these hypertrophic chondrocytes terminally differentiate and then undergo apoptosis to allow replacement of the cartilaginous template with bone [93, 94].

The many stages of differentiation are regulated by BMP, FGF, TGF $\beta$, Wnt, and Indian hedgehog (Ihh) signalling, amongst others. Both BMP and TGF $\beta$ can induce differentiation by promoting cellular condensation [92]. BMP also acts during later stages to control chondrocyte proliferation and 
Fig. 4. Expression levels of transcription factors and chondrocyte-related genes during chondrogenesis. Sox 9 is expressed from the onset of chondrogenesis when mesenchymal cells condense. Sox 9 activates L-Sox5 and Sox6, and together they promote the early stages of differentiation when chondroblasts proliferate and form columnar chondrocytes. The transition into hypertrophy is controlled by Sox 9 and Cbfa-1. During chondrogenesis, the expression of extracellular matrix proteins changes from a type-I collagen matrix to one

rich in type-II collagen, type-IX collagen, and aggrecan. Hypertrophic chondrocytes are marked by expression of type-X collagen.

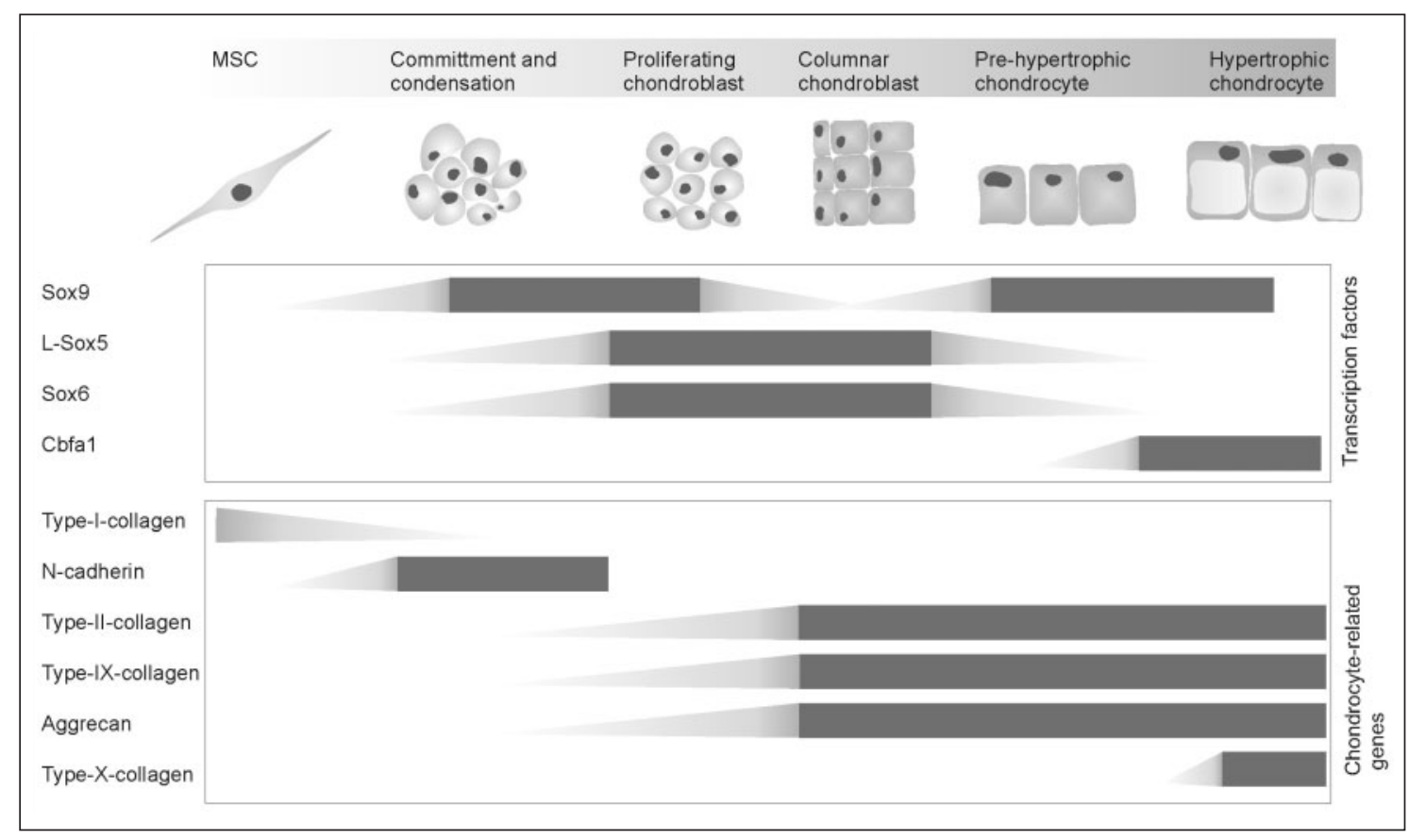

hypertrophy [95]. Signalling by Ihh with parathyroid hormone related peptide (PTHrP) is one of the best understood chondrogenic signalling pathways. Ihh is produced by proliferating chondrocytes and induces perichondrial cells, at the ends of the bone, to produce PTHrP. Together, these factors work in a negative feedback loop to control the progression of proliferative cells to chondrocyte hypertrophy [96]. FGF and Wnt signalling mechanisms also act during multiple stages of differentiation [97-100]. These signalling mechanisms ultimately exert their effects through a series of transcriptional regulators. Some of the most influential and widely studied of these include Sox5, Sox6, Sox9 and Cbfa-1 (fig. 4).

\section{Sox 9}

Sox9 is a sex-determining region Y (SRY)-related high motility group (HMG) box transcription factor. It has regulatory roles in both chondrogenic differentiation and sex determination as is demonstrated by the disease campomelic dysplasia (CD) which is caused by mutations in Sox9 and results in cartilage defects and XY sex reversal. Sox9 is the earliest known marker of chondrogenesis and has crucial roles in several stages of the differentiation process. Expression of Sox 9 is evident in the condensing mesenchymal progenitors that will become chondrocytes, and its expression remains continuous until chondrocyte hypertrophy [101]. An integral role for Sox9 in cartilage development was shown by Bi et al. [102]. Their work used embryonic stem cells deficient in Sox9 to produce mouse chimeras. There was an absence of the Sox9-deficient cells in any of the cartilage elements. Teratomas produced from the embryonic stem cells also showed an absence of any cartilage formation.

Sox 9 functions during both early and late chondrogenesis. Mice in which Sox 9 could be removed at different stages of development using Cre/LoxP recombination helped to define the temporal role of Sox 9 during chondrogenesis. Removal of Sox 9 before mesenchymal condensation resulted in mice with absent cartilage development. Loss of Sox 9 after condensation caused generalised chondrogenic dysplasia, with the arrest of differentiation at the condensation stage, indicating that cells could not complete chondrocyte differentiation [103]. These data demonstrated that Sox 9 was necessary at more than one stage of chondrogenic differentiation, and confirmed results found using heterozygous Sox 9 mutant mice. These mice died perinatally displaying cleft palate defects and deformities in many of their skeletal structures that were attributed to defects in cartilage condensation. Analysis of the embryos at different stages of gestation revealed premature mineralisation of many bones and enlarged zones of hypertrophic chondrocytes indicating that Sox 9 also controls the movement of prehypertrophic chondrocytes into hypertrophy [104]. Sox 9 can delay hypertrophy whilst increasing progression through the cell cycle $[105,106]$.

The chondrogenic effects of Sox 9 are mediated by its ability to activate genes encoding key components of the cartilage matrix. It has been demonstrated to bind to and activate elements in the promoters of Col2a1, Col9a1, Col11a2, and aggrecan [101, 107-110]. In many of these promoters, the Sox 9 elements are arranged in pairs. Changing the number of nu- 
cleotides separating these elements in the Col11a2 promoter, blocked activation by Sox 9 suggesting that it functions as a homodimer, with each Sox9 monomer binding to one recognition site [110]. Subsequent work has also identified Sox9 sites arranged in 2 pairs in the Col9a1 promoter, and it has been suggested that two Sox 9 dimers may bind these sites together in order to activate transcription [111]. There are multiple ubiquitination sites on Sox9 through which it is targeted for degradation. Akiyama et al. [112] showed that this was a mechanism used to control the transcriptional activity of Sox9 in chondrogenesis by regulating the amount of the protein present. They used inhibitors of the $26 \mathrm{~S}$ proteasome and demonstrated both increased levels of Sox 9 protein and increased levels of Col2a1 transcription.

\section{L-Sox5 and Sox6}

Sox 5 and Sox6 are highly homologous with $67 \%$ identity as a whole and over $90 \%$ homology in the DNA-binding HMG box. In contrast, they share only $50 \%$ homology with the HMG-box of Sox 9 and lack any significant homology outside of this region [113]. A major difference between the structures of Sox 5 and 6 and that of Sox 9 is that Sox 9 has a transactivation domain whilst Sox 5 and 6 do not. This means that Sox 9 can directly activate transcription of target genes whilst Sox 5 and 6 are thought to exert their effects through the recruitment and organisation of other transcriptional regulators. There are two isoforms of the Sox 5 protein of which the long form L-Sox 5 is involved in chondrogenesis. This contains an $\mathrm{N}$-terminal coiled-coil domain through which it can dimerise either with other L-Sox5 monomers or with Sox6 to form homo and heterodimers [114].

Both Sox5 and the Sox6-null mice have a few mild skeletal defects, but Sox5/Sox6 double-knockout mice show evidence of a severe generalised chondrodysplasia [113]. This indicates redundant functions for Sox 5 and Sox 6 in chondrogenic differentiation. The chondrocytes in the double-knockout mice expressed diminished levels of cartilage matrix genes resulting in the poor cartilage formation. However, condensation of the progenitor cells had occurred properly, indicating that the overlapping roles of Sox 5 and Sox6 are different to that of Sox 9 which is necessary for mesenchymal condensation as well as chondrogenic differentiation. Sox9 induces transcription of Sox 5 and Sox6, and their expression is fully dependent upon activation by Sox9. This has been demonstrated in vitro but also by the absence of Sox 5 and Sox6 in Sox9-null mice. Sox9 is not dependent on Sox 5 and Sox6 as its levels are unaffected in mice with loss of Sox 5 and Sox 6 [103, 113, 115]. The major role of Sox 5 and Sox6 is to enhance the effects of Sox9. This advocates a mechanism whereby Sox 9 induces Sox 5 and Sox6 as well as other cartilage-specific genes in pre-chondrocytes. The combined effects of Sox5, Sox6, and Sox9, often referred to as the Sox trio, then act cooperatively to further upregulate the expression of type-II, type-IX, and type-XI collagen and aggrecan in chondroblasts [116]. When expressed to- gether, the Sox trio are sufficient to induce chondrogenesis in a variety of cell types, including non-chondrogenic cells [117].

\section{Cbfa-1}

In addition to its role in osteogenesis, Cbfa- 1 also regulates chondrocyte development. Evidence for this function is present in the Cbfa-1-null mice which were used to define the pro-osteogenic role of Cbfa-1. Closer study confirmed that there were defects in the cartilage elements as well as the lack of bone formation caused by the absence of Cbfa-1-induced osteogenesis. These defects signified a failure of the chondrocytes to undergo terminal differentiation as demonstrated by the absence of cells expressing type-X collagen [118-120]. There were also defects in vascularisation of the chondrogenic elements [121].

Expression levels of Cbfa-1 peak during chondrocyte hypertrophy supporting a role for Cbfa- 1 in regulating this process [122]. Overexpression of Cbfa- 1 confirmed this observation by promoting hypertrophy in vitro and in vivo. Cbfa-1 overexpression in chick embryos caused joint fusion due to increased cartilage production, and in mice in whom Cbfa- 1 expression was targeted to prehypertrophic chondrocytes, hypertrophy and endochondral ossification were increased [120]. Experiments have also been performed using dominant-negative Cbfa-1, and these demonstrated inhibition of hypertrophy $[120,123,124]$. Together, these data provide convincing evidence that Cbfa- 1 induces chondrocyte hypertrophy. Rescue of Cbfa-1 expression in the mesenchymal condensations of Cbfa-1-null mice restores chondrocyte hypertrophy without affecting osteogenesis, indicating that this effect is direct and not just an artefact of the functions of Cbfa- 1 in osteoblast differentiation [125].

\section{Conclusions}

MSCs are candidates for a range of therapeutic applications, through their self-renewal capacity and broad differentiation potential. Identifying the transcriptional regulators that control these activities will help realise this goal. Significant progress has been made on determining the factors that influence osteogenic, chondrogenic, and adipogenic differentiation. However, many findings have been drawn from the use of transgenic animals, non-human cell lines, or mixed populations of primary bone marrow-derived human MSCs which may not necessarily reflect the behaviour of true MSCs in vivo considering interspecies disparities and imprecise MSC identity. This is also true for those MSCs that have been identified in different sources that would be exposed to unique, tissue-specific environments and signalling cues. Much less is known about the differentiation of MSCs into non-mesenchymal lineages and how this may be regulated at the transcriptional level. As technology advances alongside our knowledge of MSC biology, these issues are increasingly likely to be resolved. 


\section{References}

1 Banerjee C, Javed A, Choi JY, Green J, Rosen V, van Wijnen AJ, Stein JL, Lian JB, Stein GS: Differential regulation of the two principal Runx2/Cbfa1 $\mathrm{n}$-terminal isoforms in response to bone morphogenetic protein-2 during development of the osteoblast phenotype. Endocrinology 2001;142:40264039.

2 Zheng H, Guo Z, Ma Q, Jia H, Dang G: Cbfa1/osf2 transduced bone marrow stromal cells facilitate bone formation in vitro and in vivo. Calcif Tissue Int 2004;74:194-203.

3 Pratap J, Galindo M, Zaidi SK, Vradii D, Bhat BM, Robinson JA, Choi JY, Komori T, Stein JL, Lian JB, Stein GS, van Wijnen AJ: Cell growth regulatory role of Runx2 during proliferative expansion of preosteoblasts. Cancer Res 2003;63:5357-5362.

4 Ducy P, Zhang R, Geoffroy V, Ridall AL, Karsenty G: Osf2/Cbfa1: a transcriptional activator of osteoblast differentiation. Cell 1997;89:747-754.

5 Kern B, Shen J, Starbuck M, Karsenty G: Cbfa1 contributes to the osteoblast-specific expression of type I collagen genes. J Biol Chem 2001;276:71017107.

6 Komori T, Yagi H, Nomura S, Yamaguchi A, Sasaki K, Deguchi K, Shimizu Y, Bronson RT, Gao YH, Inada M, Sato M, Okamoto R, Kitamura Y, Yoshiki $\mathrm{S}$, Kishimoto T: Targeted disruption of Cbfa1 results in a complete lack of bone formation owing to maturational arrest of osteoblasts. Cell 1997;89: 755-764.

7 Otto F, Thornell AP, Crompton T, Denzel A, Gilmour KC, Rosewell IR, Stamp GW, Beddington RS, Mundlos S, Olsen BR, Selby PB, Owen MJ: Cbfa1, a candidate gene for cleidocranial dysplasia syndrome, is essential for osteoblast differentiation and bone development. Cell 1997;89:765-771.

$>8$ Liu W, Toyosawa S, Furuichi T, Kanatani N, Yoshida C, Liu Y, Himeno M, Narai S, Yamaguchi A, Komori T: Overexpression of Cbfa1 in osteoblasts inhibits osteoblast maturation and causes osteopenia with multiple fractures. J Cell Biol 2001;155: 157-166.

9 Nakashima K, Zhou X, Kunkel G, Zhang Z, Deng JM, Behringer RR, de Crombrugghe B: The novel zinc finger-containing transcription factor osterix is required for osteoblast differentiation and bone formation. Cell 2002;108:17-29.

10 Peng Y, Kang Q, Cheng H, Li X, Sun MH, Jiang W, Luu HH, Park JY, Haydon RC, He TC: Transcriptional characterization of bone morphogenetic proteins (BMPs)-mediated osteogenic signaling. J Cell Biochem 2003;90:1149-1165.

11 Kanaan RA, Kanaan LA: Transforming growth factor beta1, bone connection. Med Sci Monit 2006;12: RA164-RA169.

12 Nakashima K, de Crombrugghe B: Transcriptional mechanisms in osteoblast differentiation and bone formation. Trends Genet 2003;19:458-466.

-13 Tai G, Polak JM, Bishop AE, Christodoulou I, Buttery LD: Differentiation of osteoblasts from murine embryonic stem cells by overexpression of the transcriptional factor osterix. Tissue Eng 2004; 10:1456-1466.

14 Tu Q, Valverde P, Chen J: Osterix enhances proliferation and osteogenic potential of bone marrow stromal cells. Biochem Biophys Res Commun 2006; 341:1257-1265.

-15 Kim YJ, Kim HN, Park EK, Lee BH, Ryoo HM, Kim SY, Kim IS, Stein JL, Lian JB, Stein GS, van Wijnen AJ, Choi JY: The bone-related Zn finger transcription factor Osterix promotes proliferation of mesenchymal cells. Gene 2006;366:145-151.
6 Kurata H, Guillot PV, Chan J, Fisk NM: Osterix induces osteogenic gene expression but not differentiation in primary human fetal mesenchymal stem cells. Tissue Eng 2007;13:1513-1523.

17 Simeone A, Acampora D, Pannese M, D'Esposito M, Stornaiuolo A, Gulisano M, Mallamaci A, Kastury K, Druck T, Huebner K, .: Cloning and characterization of two members of the vertebrate Dlx gene family. Proc Natl Acad Sci U S A 1994;91: 2250-2254.

18 Zhao GQ, Zhao S, Zhou X, Eberspaecher H, Solursh M, de Crombrugghe B: rDlx, a novel distalless-like homeoprotein is expressed in developing cartilages and discrete neuronal tissues. Dev Biol 1994;164:37-51.

19 Ryoo HM, Hoffmann HM, Beumer T, Frenkel B, Towler DA, Stein GS, Stein JL, van Wijnen AJ, Lian JB: Stage-specific expression of Dlx-5 during osteoblast differentiation: involvement in regulation of osteocalcin gene expression. Mol Endocrinol 1997;11:1681-1694.

20 Lee MH, Javed A, Kim HJ, Shin HI, Gutierrez S, Choi JY, Rosen V, Stein JL, van Wijnen AJ, Stein GS, Lian JB, Ryoo HM: Transient upregulation of CBFA1 in response to bone morphogenetic protein-2 and transforming growth factor beta1 in $\mathrm{C} 2 \mathrm{C} 12$ myogenic cells coincides with suppression of the myogenic phenotype but is not sufficient for osteoblast differentiation. J Cell Biochem 1999;73: $114-125$.

21 Shirakabe K, Terasawa K, Miyama K, Shibuya H, Nishida E: Regulation of the activity of the transcription factor Runx2 by two homeobox proteins, Msx2 and Dlx5. Genes Cells 2001;6:851-856.

22 Hassan MQ, Javed A, Morasso MI, Karlin J, Montecino M, van Wijnen AJ, Stein GS, Stein JL, Lian JB: Dlx3 transcriptional regulation of osteoblast differentiation: temporal recruitment of Msx2, Dlx3, and Dlx5 homeodomain proteins to chromatin of the osteocalcin gene. Mol Cell Biol 2004;24:9248-9261.

23 Hassan MQ, Tare RS, Lee SH, Mandeville M, Morasso MI, Javed A, van Wijnen AJ, Stein JL, Stein GS, Lian JB: BMP2 commitment to the osteogenic lineage involves activation of Runx 2 by DLX3 and a homeodomain transcriptional network. J Biol Chem 2006;281:40515-40526.

24 Acampora D, Merlo GR, Paleari L, Zerega B, Postiglione MP, Mantero S, Bober E, Barbieri O, Simeone A, Levi G: Craniofacial, vestibular and bone defects in mice lacking the Distal-less-related gene Dlx5. Development 1999;126:3795-3809.

25 Depew MJ, Lufkin T, Rubenstein JL: Specification of jaw subdivisions by Dlx genes. Science 2002;298: 381-385.

26 Robledo RF, Rajan L, Li X, Lufkin T: The Dlx5 and Dlx6 homeobox genes are essential for craniofacial, axial, and appendicular skeletal development. Genes Dev 2002;16:1089-1101.

27 Miyama K, Yamada G, Yamamoto TS, Takagi C, Miyado K, Sakai M, Ueno N, Shibuya H: A BMPinducible gene, dlx5, regulates osteoblast differentiation and mesoderm induction. Dev Biol 1999;208: 123-133.

28 Tadic T, Dodig M, Erceg I, Marijanovic I, Mina M, Kalajzic Z, Velonis D, Kronenberg MS, Kosher RA, Ferrari D, Lichtler AC: Overexpression of Dlx5 in chicken calvarial cells accelerates osteoblastic differentiation. J Bone Miner Res 2002;17:1008-1014.

29 Morasso MI, Grinberg A, Robinson G, Sargent TD, Mahon KA: Placental failure in mice lacking the homeobox gene Dlx3. Proc Natl Acad Sci U S A 1999;96:162-167.
30 Ryoo HM, Lee MH, Kim YJ: Critical molecular switches involved in BMP-2-induced osteogenic differentiation of mesenchymal cells. Gene 2006; 366:51-57.

31 Kim YJ, Lee MH, Wozney JM, Cho JY, Ryoo HM: Bone morphogenetic protein-2-induced alkaline phosphatase expression is stimulated by Dlx 5 and repressed by Msx2. J Biol Chem 2004;279:5077350780.

32 Lee MH, Kim YJ, Yoon WJ, Kim JI, Kim BG, Hwang YS, Wozney JM, Chi XZ, Bae SC, Choi KY, Cho JY, Choi JY, Ryoo HM: Dlx5 specifically regulates Runx 2 type II expression by binding to homeodomain-response elements in the Runx2 dista promoter. J Biol Chem 2005;280:35579-35587.

33 Holleville N, Mateos S, Bontoux M, Bollerot K, Monsoro-Burq AH: Dlx5 drives Runx2 expression and osteogenic differentiation in developing cranial suture mesenchyme. Dev Biol 2007;304:860-874.

34 Luo T, Matsuo-Takasaki M, Lim JH, Sargent TD: Differential regulation of Dlx gene expression by a BMP morphogenetic gradient. Int J Dev Biol 2001; 45:681-684.

35 Park GT, Morasso MI: Bone morphogenetic protein-2 (BMP-2) transactivates Dlx3 through Smad1 and Smad4: alternative mode for Dlx3 induction in mouse keratinocytes. Nucleic Acids Res 2002;30: 515-522.

36 Harris SE, Guo D, Harris MA, Krishnaswamy A, Lichtler A: Transcriptional regulation of BMP-2 activated genes in osteoblasts using gene expression microarray analysis: role of Dlx2 and Dlx 5 transcription factors. Front Biosci 2003;8:s1249-s1265.

- 37 Liu T, Gao Y, Sakamoto K, Minamizato T, Furukawa K, Tsukazaki T, Shibata Y, Bessho K, Komori T, Yamaguchi A: BMP-2 promotes differentiation of osteoblasts and chondroblasts in Runx2-deficient cell lines. J Cell Physiol 2007;211: 728-735.

38 Lee MH, Kim YJ, Kim HJ, Park HD, Kang AR, Kyung HM, Sung JH, Wozney JM, Kim HJ, Ryoo HM: BMP-2-induced Runx2 expression is mediated by Dlx5, and TGF-beta 1 opposes the BMP-2induced osteoblast differentiation by suppression of Dlx5 expression. J Biol Chem 2003;278:3438734394.

39 Dodig M, Tadic T, Kronenberg MS, Dacic S, Liu YH, Maxson R, Rowe DW, Lichtler AC: Ectopic Msx2 overexpression inhibits and Msx2 antisense stimulates calvarial osteoblast differentiation. Dev Biol 1999;209:298-307.

40 Yoshizawa T, Takizawa F, Iizawa F, Ishibashi O, Kawashima H, Matsuda A, Endo N, Kawashima H: Homeobox protein MSX2 acts as a molecular defense mechanism for preventing ossification in ligament fibroblasts. Mol Cell Biol 2004;24:3460-3472.

41 Ichida F, Nishimura R, Hata K, Matsubara T, Ikeda F, Hisada K, Yatani H, Cao X, Komori T, Yamaguchi A, Yoneda T: Reciprocal roles of MSX2 in regulation of osteoblast and adipocyte differentiation. J Biol Chem 2004;279:34015-34022.

42 Satokata I, Maas R: Msx1 deficient mice exhibit cleft palate and abnormalities of craniofacial and tooth development. Nat Genet 1994;6:348-356.

43 Lallemand Y, Nicola MA, Ramos C, Bach A, Cloment CS, Robert B: Analysis of Msx1; Msx2 double mutants reveals multiple roles for Msx genes in limb development. Development 2005;132: 3003-3014. 
44 Roca H, Phimphilai M, Gopalakrishnan R, Xiao G, Franceschi RT: Cooperative interactions between RUNX2 and homeodomain protein-binding sites are critical for the osteoblast-specific expression of the bone sialoprotein gene. J Biol Chem 2005;280: 30845-30855.

45 Wolf C, Thisse C, Stoetzel C, Thisse B, Gerlinger P, Perrin-Schmitt F: The M-twist gene of Mus is expressed in subsets of mesodermal cells and is closely related to the Xenopus X-twi and the Drosophila twist genes. Dev Biol 1991;143:363-373.

46 Li L, Cserjesi P, Olson EN: Dermo-1: a novel twistrelated bHLH protein expressed in the developing dermis. Dev Biol 1995;172:280-292.

47 Sosic D, Richardson JA, Yu K, Ornitz DM, Olson EN: Twist regulates cytokine gene expression through a negative feedback loop that represses NF-kappaB activity. Cell 2003;112:169-180.

48 Kronenberg HM: Twist genes regulate Runx2 and bone formation. Dev Cell 2004;6:317-318.

>49 Hayashi M, Nimura K, Kashiwagi K, Harada T, Takaoka K, Kato H, Tamai K, Kaneda Y: Comparative roles of Twist-1 and Id1 in transcriptional regulation by BMP signaling. J Cell Sci 2007;120: 1350-1357.

50 Yousfi M, Lasmoles F, Marie PJ: TWIST inactivation reduces CBFA1/RUNX2 expression and DNA binding to the osteocalcin promoter in osteoblasts. Biochem Biophys Res Commun 2002;297:641-644.

-51 Bialek P, Kern B, Yang X, Schrock M, Sosic D, Hong N, Wu H, Yu K, Ornitz DM, Olson EN, Justice MJ, Karsenty G: A twist code determines the onset of osteoblast differentiation. Dev Cell 2004;6: 423-435.

52 MacDougald OA, Mandrup S: Adipogenesis: forces that tip the scales. Trends Endocrinol Metab 2002; 13:5-11.

53 Fajas L, Auboeuf D, Raspe E, Schoonjans K, Lefebvre AM, Saladin R, Najib J, Laville M, Fruchart JC, Deeb S, Vidal-Puig A, Flier J, Briggs MR, Staels B, Vidal H, Auwerx J: The organization, promoter analysis, and expression of the human PPARgamma gene. J Biol Chem 1997;272:18779-18789.

54 Fajas L, Fruchart JC, Auwerx J: Transcriptional control of adipogenesis. Curr Opin Cell Biol 1998; 10:165-173.

55 Mueller E, Drori S, Aiyer A, Yie J, Sarraf P, Chen H, Hauser S, Rosen ED, Ge K, Roeder RG, Spiegelman BM: Genetic analysis of adipogenesis through peroxisome proliferator-activated receptor gamma isoforms. J Biol Chem 2002;277:41925-41930.

56 Loftus TM, Lane MD: Modulating the transcriptional control of adipogenesis. Curr Opin Genet Dev 1997;7:603-608.

57 Tontonoz P, Hu E, Spiegelman BM: Stimulation of adipogenesis in fibroblasts by PPAR gamma 2, a lipid-activated transcription factor. Cell 1994;79: 1147-1156.

$58 \mathrm{Hu}$ E, Tontonoz P, Spiegelman BM: Transdifferentiation of myoblasts by the adipogenic transcription factors PPAR gamma and C/EBP alpha. Proc Natl Acad Sci U S A 1995;92:9856-9860.

59 Rosen ED, Hsu CH, Wang X, Sakai S, Freeman MW, Gonzalez FJ, Spiegelman BM: C/EBPalpha induces adipogenesis through PPARgamma: a unified pathway. Genes Dev 2002;16:22-26.

-60 Zhang J, Fu M, Cui T, Xiong C, Xu K, Zhong W, Xiao Y, Floyd D, Liang J, Li E, Song Q, Chen YE: Selective disruption of PPARgamma 2 impairs the development of adipose tissue and insulin sensitivity. Proc Natl Acad Sci U S A 2004;101:1070310708
61 Tontonoz P, Hu E, Spiegelman BM: Regulation of adipocyte gene expression and differentiation by peroxisome proliferator activated receptor gamma. Curr Opin Genet Dev 1995;5:571-576.

62 Adams M, Montague CT, Prins JB, Holder JC, Smith SA, Sanders L, Digby JE, Sewter CP, Lazar MA, Chatterjee VK, O'Rahilly S: Activators of peroxisome proliferator-activated receptor gamma have depot-specific effects on human preadipocyte differentiation. J Clin Invest 1997;100:3149-3153.

63 Gearing KL, Gottlicher M, Teboul M, Widmark E, Gustafsson JA: Interaction of the peroxisome-proliferator-activated receptor and retinoid $\leftrightarrow$ receptor. Proc Natl Acad Sci U S A 1993;90:1440-1444.

64 Juge-Aubry C, Pernin A, Favez T, Burger AG, Wahli W, Meier CA, Desvergne B: DNA binding properties of peroxisome proliferator-activated receptor subtypes on various natural peroxisome proliferator response elements. Importance of the 5'-flanking region. J Biol Chem 1997;272: 25252-25259.

65 Burns KA, Vanden Heuvel JP: Modulation of PPAR activity via phosphorylation. Biochim Biophys Acta 2007;1771:952-960.

66 Powell E, Kuhn P, Xu W: Nuclear receptor cofactors in PPARgamma-mediated adipogenesis and adipocyte energy metabolism. PPAR Res 2006; 2007:53843.

67 Zhu Y, Qi C, Calandra C, Rao MS, Reddy JK: Cloning and identification of mouse steroid receptor coactivator-1 (mSRC-1), as a coactivator of peroxisome proliferator-activated receptor gamma. Gene Expr 1996;6:185-195.

68 Zhu Y, Qi C, Jain S, Rao MS, Reddy JK: Isolation and characterization of PBP, a protein that interacts with peroxisome proliferator-activated receptor. J Biol Chem 1997;272:25500-25506.

69 Xu HE, Lambert MH, Montana VG, Parks DJ, Blanchard SG, Brown PJ, Sternbach DD, Lehmann JM, Wisely GB, Willson TM, Kliewer SA, Milburn MV: Molecular recognition of fatty acids by peroxisome proliferator-activated receptors. Mol Cell 1999;3:397-403.

70 Xu J, Storer PD, Chavis JA, Racke MK, Drew PD: Agonists for the peroxisome proliferator-activated receptor-alpha and the retinoid $\times$ receptor inhibit inflammatory responses of microglia. J Neurosci Res 2005;81:403-411.

71 Guan HP, Ishizuka T, Chui PC, Lehrke M, Lazar MA: Corepressors selectively control the transcriptional activity of PPARgamma in adipocytes. Genes Dev 2005;19:453-461.

72 Tang QQ, Zhang JW, Daniel LM: Sequential gene promoter interactions by C/EBPbeta, C/EBPalpha, and PPARgamma during adipogenesis. Biochem Biophys Res Commun 2004;318:213-218.

73 Linhart HG, Ishimura-Oka K, DeMayo F, Kibe T, Repka D, Poindexter B, Bick RJ, Darlington GJ: $\mathrm{C} / \mathrm{EBPalph}$ is required for differentiation of white, but not brown, adipose tissue. Proc Natl Acad Sci U S A 2001;98:12532-12537.

74 Tang QQ, Otto TC, Lane MD: CCAAT/enhancerbinding protein beta is required for mitotic clonal expansion during adipogenesis. Proc Natl Acad Sci U S A 2003;100:850-855.

75 Tang QQ, Lane MD: Role of C/EBP homologous protein $(\mathrm{CHOP}-10)$ in the programmed activation of CCAAT/enhancer-binding protein-beta during adipogenesis. Proc Natl Acad Sci U S A 2000;97: 12446-12450.

76 Wu Z, Puigserver P, Spiegelman BM: Transcriptional activation of adipogenesis. Curr Opin Cell Biol 1999;11:689-694.
7 Barak Y, Nelson MC, Ong ES, Jones YZ, RuizLozano P, Chien KR, Koder A, Evans RM: PPAR gamma is required for placental, cardiac, and adipose tissue development. Mol Cell 1999;4:585-595.

78 Kubota N, Terauchi Y, Miki H, Tamemoto H, Yamauchi T, Komeda K, Satoh S, Nakano R, Ishi C, Sugiyama T, Eto K, Tsubamoto Y, Okuno A Murakami K, Sekihara H, Hasegawa G, Naito M, Toyoshima Y, Tanaka S, Shiota K, Kitamura T, Fujita T, Ezaki O, Aizawa S, Kadowaki T: PPAR gamma mediates high-fat diet-induced adipocyte hypertrophy and insulin resistance. Mol Cell 1999;4: 597-609.

79 Tontonoz P, Kim JB, Graves RA, Spiegelman BM: ADD1: a novel helix-loop-helix transcription factor associated with adipocyte determination and differentiation. Mol Cell Biol 1993;13:4753-4759.

80 Ericsson J, Jackson SM, Kim JB, Spiegelman BM Edwards PA: Identification of glycerol-3-phosphate acyltransferase as an adipocyte determination and differentiation factor 1- and sterol regulatory element-binding protein-responsive gene. J Biol Chem 1997;272:7298-7305.

$81 \mathrm{Kim}$ JB, Spiegelman BM: ADD1/SREBP1 promotes adipocyte differentiation and gene expression linked to fatty acid metabolism. Genes Dev 1996;10:1096-1107.

82 Fajas L, Schoonjans K, Gelman L, Kim JB, Najib J, Martin G, Fruchart JC, Briggs M, Spiegelman BM Auwerx J: Regulation of peroxisome proliferatoractivated receptor gamma expression by adipocyte differentiation and determination factor $1 /$ sterol regulatory element binding protein 1 : implications for adipocyte differentiation and metabolism. Mol Cell Biol 1999;19:5495-5503.

83 Kim JB, Wright HM, Wright M, Spiegelman BM: ADD1/SREBP1 activates PPARgamma through the production of endogenous ligand. Proc Natl Acad Sci U S A 1998;95:4333-4337.

84 Hayes SA, Miller JM, Hoshizaki DK: Serpent, a GATA-like transcription factor gene, induces fat-cell development in Drosophila melanogaster. Development 2001;128:1193-1200.

85 Tong Q, Tsai J, Tan G, Dalgin G, Hotamisligil GS: Interaction between GATA and the C/EBP family of transcription factors is critical in GATA-mediated suppression of adipocyte differentiation. Mol Cell Biol 2005;25:706-715.

86 Okitsu Y, Takahashi S, Minegishi N, Kameoka J, Kaku M, Yamamoto M, Sasaki T, Harigae H: Regulation of adipocyte differentiation of bone marrow stromal cells by transcription factor GATA-2. Biochem Biophys Res Commun 2007;364:383-387.

87 Moldes M, Lasnier F, Feve B, Pairault J, Djian P: Id3 prevents differentiation of preadipose cells. Mol Cell Biol 1997;17:1796-1804.

88 Moldes M, Boizard M, Liepvre XL, Feve B, Dugail I, Pairault J: Functional antagonism between inhibitor of DNA binding (Id) and adipocyte determination and differentiation factor 1 /sterol regulatory element-binding protein-1c (ADD1/SREBP1c) trans-factors for the regulation of fatty acid synthase promoter in adipocytes. Biochem J 1999;344 Pt 3:873-880.

89 Huang H, Lane MD, Tang QQ: Effect of serum on the down-regulation of CHOP-10 during differentiation of 3T3-L1 preadipocytes. Biochem Biophys Res Commun 2005;338:1185-1188.

90 Batchvarova N, Wang XZ, Ron D: Inhibition of adipogenesis by the stress-induced protein $\mathrm{CHOP}$ (Gadd153). EMBO J 1995;14:4654-4661.

91 Delise AM, Tuan RS: Analysis of N-cadherin function in limb mesenchymal chondrogenesis in vitro. Dev Dyn 2002;225:195-204. 
92 Haas AR, Tuan RS: Chondrogenic differentiation of murine $\mathrm{C} 3 \mathrm{H} 10 \mathrm{~T} 1 / 2$ multipotential mesenchymal cells: II. Stimulation by bone morphogenetic protein-2 requires modulation of $\mathrm{N}$-cadherin expression and function. Differentiation 1999;64: $77-89$.

93 Lefebvre V, Smits P: Transcriptional control of chondrocyte fate and differentiation. Birth Defects Res C Embryo Today 2005;75:200-212.

94 Goldring MB, Tsuchimochi K, Ijiri K: The contro of chondrogenesis. J Cell Biochem 2006;97:33-44.

95 Volk SW, Luvalle P, Leask T, Leboy PS: A BMP responsive transcriptional region in the chicken type X collagen gene. J Bone Miner Res 1998;13: 1521-1529.

96 Kronenberg HM: PTHrP and skeletal development. Ann N Y Acad Sci 2006;1068:1-13.

97 Davidson D, Blanc A, Filion D, Wang H, Plut P, Pfeffer G, Buschmann MD, Henderson JE: Fibroblast growth factor (FGF) 18 signals through FGF receptor 3 to promote chondrogenesis. $\mathrm{J}$ Bio Chem 2005;280:20509-20515.

98 Ohbayashi N, Shibayama M, Kurotaki Y, Imanish M, Fujimori T, Itoh N, Takada S: FGF18 is required for normal cell proliferation and differentiation during osteogenesis and chondrogenesis. Genes Dev 2002;16:870-879.

99 Fischer L, Boland G, Tuan RS: Wnt-3A enhances bone morphogenetic protein-2-mediated chondrogenesis of murine C3H10T1/2 mesenchymal cells. J Biol Chem 2002;277:30870-30878.

100 Kengaku M, Capdevila J, Rodriguez-Esteban C, De La PJ, Johnson RL, Belmonte JC, Tabin CJ: Distinct WNT pathways regulating AER formation and dorsoventral polarity in the chick limb bud. Science 1998;280:1274-1277.

101 Zhao Q, Eberspaecher H, Lefebvre V, de Crombrugghe B: Parallel expression of Sox 9 and Col2a1 in cells undergoing chondrogenesis. Dev Dyn 1997;209:377-386.

102 Bi W, Deng JM, Zhang Z, Behringer RR, de Crombrugghe B: Sox 9 is required for cartilage formation. Nat Genet 1999;22:85-89.

103 Akiyama H, Chaboissier MC, Martin JF, Schedl A, de Crombrugghe B: The transcription factor Sox 9 has essential roles in successive steps of the chondrocyte differentiation pathway and is required for expression of Sox 5 and Sox6. Genes Dev 2002;16 2813-2828.

104 Bi W, Huang W, Whitworth DJ, Deng JM, Zhang Z, Behringer RR, de Crombrugghe B: Haploinsufficiency of Sox 9 results in defective cartilage primordia and premature skeletal mineralization. Proc Natl Acad Sci U S A 2001;98:6698-6703.
105 Akiyama H, Lyons JP, Mori-Akiyama Y, Yang X, Zhang R, Zhang Z, Deng JM, Taketo MM, Nakamura T, Behringer RR, McCrea PD, de Crombrugghe B: Interactions between Sox 9 and beta-catenin control chondrocyte differentiation. Genes Dev 2004;18:1072-1087.

106 Panda DK, Miao D, Lefebvre V, Hendy GN, Goltzman D: The transcription factor SOX9 regulates cell cycle and differentiation genes in chondrocytic CFK2 cells. J Biol Chem 2001;276: 41229-41236.

107 Bell DM, Leung KK, Wheatley SC, Ng LJ, Zhou S, Ling KW, Sham MH, Koopman P, Tam PP, Cheah KS: SOX9 directly regulates the type-II collagen gene. Nat Genet 1997;16:174-178.

108 Bridgewater LC, Lefebvre V, de Crombrugghe B: Chondrocyte-specific enhancer elements in the Col11a2 gene resemble the Col2a1 tissue-specific enhancer. J Biol Chem 1998;273:14998-15006.

109 Sekiya I, Tsuji K, Koopman P, Watanabe H, Yamada Y, Shinomiya K, Nifuji A, Noda M: SOX9 enhances aggrecan gene promoter/enhancer activity and is up-regulated by retinoic acid in a cartilage-derived cell line, TC6. J Biol Chem 2000;275: 10738-10744.

110 Bridgewater LC, Walker MD, Miller GC, Ellison TA, Holsinger LD, Potter JL, Jackson TL, Chen RK, Winkel VL, Zhang Z, McKinney S, de Crombrugghe B: Adjacent DNA sequences modulate Sox 9 transcriptional activation at paired Sox sites in three chondrocyte-specific enhancer elements. Nucleic Acids Res 2003;31:1541-1553.

111 Genzer MA, Bridgewater LC: A Col9a1 enhancer element activated by two interdependent SOX9 dimers. Nucleic Acids Res 2007;35:1178-1186.

112 Akiyama H, Kamitani T, Yang X, Kandyil R, Bridgewater LC, Fellous M, Mori-Akiyama Y, de Crombrugghe B: The transcription factor Sox9 is degraded by the ubiquitin-proteasome system and stabilized by a mutation in a ubiquitin-target site. Matrix Biol 2005;23:499-505.

113 Smits P, Li P, Mandel J, Zhang Z, Deng JM, Behringer RR, de Crombrugghe B, Lefebvre V: The transcription factors L-Sox 5 and Sox6 are essential for cartilage formation. Dev Cell 2001;1: 277-290.

114 Lefebvre V, Li P, de Crombrugghe B: A new long form of Sox5 (L-Sox5), Sox6 and Sox9 are coexpressed in chondrogenesis and cooperatively activate the type II collagen gene. EMBO J 1998;17: 5718-5733.
115 Smits P, Dy P, Mitra S, Lefebvre V: Sox5 and Sox6 are needed to develop and maintain source, columnar, and hypertrophic chondrocytes in the cartilage growth plate. J Cell Biol 2004;164: 747-758.

116 Lefebvre V, Behringer RR, de Crombrugghe B: L-Sox5, Sox6 and Sox9 control essential steps of the chondrocyte differentiation pathway. Osteoarthritis Cartilage 2001;9(suppl A):S69-S75.

117 Ikeda T, Kamekura S, Mabuchi A, Kou I, Seki S Takato T, Nakamura K, Kawaguchi H, Ikegawa S, Chung UI: The combination of SOX5, SOX6, and SOX9 (the SOX trio) provides signals sufficient for induction of permanent cartilage. Arthritis Rheum 2004;50:3561-3573.

118 Inada M, Yasui T, Nomura S, Miyake S, Deguchi K, Himeno M, Sato M, Yamagiwa H, Kimura T, Yasui N, Ochi T, Endo N, Kitamura Y, Kishimoto T, Komori T: Maturational disturbance of chondrocytes in Cbfa1-deficient mice. Dev Dyn 1999; 214:279-290.

119 Kim IS, Otto F, Zabel B, Mundlos S: Regulation of chondrocyte differentiation by Cbfa1. Mech Dev 1999;80:159-170.

120 Enomoto-Iwamoto M, Enomoto H, Komori T, Iwamoto M: Participation of Cbfa1 in regulation of chondrocyte maturation. Osteoarthritis Cartilage 2001;9(suppl A):S76-S84.

121 Stricker S, Fundele R, Vortkamp A, Mundlos S: Role of Runx genes in chondrocyte differentiation. Dev Biol 2002;245:95-108.

122 Rabie AB, Tang GH, Hagg U: Cbfa1 couples chondrocytes maturation and endochondral ossification in rat mandibular condylar cartilage. Arch Oral Biol 2004;49:109-118.

123 Ueta C, Iwamoto M, Kanatani N, Yoshida C, Liu Y, Enomoto-Iwamoto M, Ohmori T, Enomoto H, Nakata K, Takada K, Kurisu K, Komori T: Skeletal malformations caused by overexpression of Cbfa1 or its dominant negative form in chondrocytes. $\mathrm{J}$ Cell Biol 2001;153:87-100.

124 Enomoto H, Enomoto-Iwamoto M, Iwamoto M, Nomura S, Himeno M, Kitamura Y, Kishimoto T, Komori $\mathrm{T}$ : Cbfa1 is a positive regulatory factor in chondrocyte maturation. J Biol Chem 2000;275: 8695-8702.

125 Takeda S, Bonnamy JP, Owen MJ, Ducy P, Karsenty G: Continuous expression of Cbfa1 in nonhypertrophic chondrocytes uncovers its ability to induce hypertrophic chondrocyte differentiation and partially rescues Cbfa1-deficient mice. Genes Dev 2001;15:467-481. 